\title{
Biological Aspects of Orius similis Zheng Reared on Two Preys at Three Constant Temperatures
}

\author{
Marwa Elsayed Sanad Amer ${ }^{1,2}$, Yueguan $\mathrm{Fu}^{1}$ and Liming Niu ${ }^{1}$ \\ 1. Department of Integrated Pest Management, Environmental and Plant Protection Institute (EPPI), Chinese Academy of Tropical \\ Agricultural Science, Haikou City, Hainan Province 571101, China \\ 2. Department of Scale Insects and Mealybugs, Plant Protection Research Institute (PPRI), Agricultural Research Center (ARC), \\ Dokki, Giza 12611, Egypt
}

\begin{abstract}
Mass-rearing of Orius similis Zheng on two preys, Aphis craccivora Koch and eggs of Corcyra cephalonica Stainton at three constant temperatures (22, 26 and $30{ }^{\circ} \mathrm{C}$ ) and 60\% $\pm 10 \% \mathrm{RH}$ and 16:8 L/D photoperiod under laboratory conditions was investigated to study the effect of different temperatures and different preys on the biology of $O$. similis. The highest survival rate (\%) of nymphal stages was $81.14 \%$ and the longest oviposition period for females (20.6 d) was recorded at $26{ }^{\circ} \mathrm{C}$. Also, the highest fecundity of female also recorded at $26^{\circ} \mathrm{C}$. The highest rate of nymphal feeding consumption was (122.5 individuals of A. cracivora) also, recorded at $26^{\circ} \mathrm{C}$. As well as, the two preys had significant effects on the biological characteristics of $O$. similis. The highest survival rate for nymphal stage was recorded when $O$. similis nymphs fed on $A$. cracivora. Therefore, the longest survival rate was founded in the nymphs which fed on the individuals of A. cracivora. During the nymphal period of $O$. similis which consumed more individuals of $A$. cracivora than the eggs of $C$. cephalonica. These results on the effect of three constant temperatures and two preys on the biology of $O$. similis will share to improve the rearing of $O$. similis in biological control agents in China and share to suppress the population of pests in field and greenhouse.
\end{abstract}

Key words: Orius similis Zheng, biological characteristics, feeding consumption.

\section{Introduction}

Aphis craccivora Koch (cowpea aphid) (Homoptera: Aphididae) causes momentous damages which depend on sucking plant sap from leaves. As well as, it is considered one of the most widespread pests in china which causing dangerous damages as well as, there were including direct and indirect damages to crops. The direct damage occurs when the aphids cause injury by feeding and when, the indirect damage refers primarily to the transmission of plant viruses [1]. This aphid feeds on large numbers of young leaves, mostly on the undersurface and also on tender parts and cause enormous damage. They suck the cells of the plant leaves, low its vitality, turn them yellow and crinkled. Aphids are usually controlled by different chemical

Corresponding author: Yueguan Fu, professor, research field: integrated pest management. insecticides which may pollute the environmental system. The extensive using of insecticides and repeating it lead to imbalance in the ecosystem between these pests and natural enemies. All scientists must support and enhance the use of safe control methods such as biological control by using natural enemies. Predators are the most useful groups of natural enemies which play an effective role against insect pests. The relationship between the pests as favorable preys and their predators enable to know how these predators can lead to suppression the density of these insect pests and environmental balance occurs. The egg of rice moth Corcyra cephalonica and aphids is one of the most laboratory host preys mostly used in rearing Oruis species in the world [2].

The bug Orius similis Zheng (Hemiptera: Anthocoridae) is one of the most effectiveness biological control agents of insect pests in China [3]. 
As well as, it is a polyphagous natural enemy that has a lot of preys such as aphids [4], thrips, spider mites [5] and the eggs of moth [6-8].

Rearing $O$. similis in large numbers at laboratory and then releasing their nymphs and adults in the field will support the biological control of these insect pests, decrease their population in the field and could lead to the reduction of pesticide use $[9,10]$.

Therefore, the present work was carried out to study the biological aspects of the $O$. similis Zheng and the effect of feeding on different preys at three constant temperatures on biological characteristics at laboratory conditions in Hainan, China.

\section{Materials and Methods}

\subsection{Mass Production of the Cowpea Aphid, A. craccivora Koch}

Vicia faba seeds were planted in plastic trays (25 $\mathrm{cm} \times 40 \mathrm{~cm} \times 15 \mathrm{~cm}$ ) contained (peat moss). The seeds were planted at a depth of $1-2 \mathrm{~cm}$ below the soil surface and were irrigated and fertilized these trays. After one week from cultivation, when the first leaflet appeared, bean leaves were infested with $A$. craccivora which distributed over the new leaves.

The infested trays were monitored until the population of $A$. craccivora increased and became suitable for use as prey to $O$. similis. A. craccivora colonies were reared under laboratory conditions (22 $\pm 3{ }^{\circ} \mathrm{C}$ and $\left.60 \% \pm 10 \% \mathrm{RH}\right)$ on broad beans. Such leaves of beans were infested by different stages of $A$. craccivora and were kept in metallic cages $(100 \mathrm{~cm} \times$ $135 \mathrm{~cm} \times 135 \mathrm{~cm})$ with nylon gauze sides. The infested plants were irrigated and fertilized. This method was described by Mangoud [11]. A. craccivora were collected from infested broad beans, cultivated in Hainan, China.

\subsection{Mass Production of O. similis Zheng}

The experiments were carried out under laboratory conditions at $26 \pm 2{ }^{\circ} \mathrm{C}, 60 \% \pm 10 \% \mathrm{RH}$ and 16:8 L/D photoperiod. Mass rearing of both prey and predator was carried out in the laboratory, of the $O$. similis were obtained from: Beijing Kuo: Ye Bio-Tec Company (China) and had been reared for several two generations under laboratory conditions. The predators were reared using the methods described by Isenhor and Yeargan [12]. Adults and nymphs of $O$. similis were collected to be kept in plastic jars of $10 \mathrm{~cm}$ (diameter) $\times 20 \mathrm{~cm}$ (height) covered with muslin and held in place by means of rubber bands. Each jar was provided with both small balls of white foam to reduce cannibalism behavior and sufficient quantities of $C$. cephalonica eggs as food supply for the enclosed predators. A piece of bean pod (Phaseolus vulgaris) was provided in each jar as an ovipostional substrate [13]. Eggs were inserted into the tissue of bean pods. Bean pods with newly deposited eggs inside were kept in plastic jars previously described. Jars were examined daily until hatching. Soon after hatching, newly-hatched nymphs on bean pods were carefully transferred to plastic jars and provided with eggs of $C$. cephalonica and small balls of white foam to reduce cannibalism. The amount of food was increased with the nymphal development. Immediately after emergence of adults, they were sexed and kept in plastic jars provided with food. The procedure was repeated for two successive generations and all records data concerning the different developmental stages, adults longevity, fecundity and other biological investigations were recorded under the laboratory conditions.

\subsection{Effect of Different Preys on the Immature Stages}

The effect of eggs of $C$. cephalonica and nymphs of A. cracivora on the developmental stages of the $O$. similis, percentages of survival rate and predation capacity was determined at three constant temperatures (22, 26 and $30{ }^{\circ} \mathrm{C}$ ). New nymphs were separated into small Petri dishes $(9 \mathrm{~cm}$ (diameter) $\times$ $1.5 \mathrm{~cm}$ (height)) by using a small hair brush and respirator. There were 10 replicates for each prey treatment. Each nymph was provided with the two 
investigated prey (eggs of $C$. cephalonica and nymphs of A. cracivora). Eggs of C. cephalonica were put in small glass Petri dishes and also the container provided with plastic vials $(5 \mathrm{~mL})$ filled with cotton and moistened with honey water (70\%), were placed inside. Another prey was provided to the predators on small leaf discs of bean leaves cut from host plants used in their colony's maintenance.

Each container was daily observed to study the $O$. similis developmental stages and the number of prey which consumed. Predation capacity was determined by using the binocular microscope. New prey was daily provided until the $O$. similis completed development or died. Data of the developmental time and prey consumption for each instar were mentioned by El-Husseini et al. [14]. After adult eclosion, the sex ratio of the $O$. similis was determined and females were reared on the two preys.

2.4 Effect of Different Preys on the Longevity and Female Fecundity of $O$. similis

The fecundity and longevity for adults emerging from immature developmental stage were determined. Newly emerged adults of $O$. similis for the two prey treatments were paired (one female with one male) and separated in Petri dishes $(9 \mathrm{~cm}$ (diameter) $\times 1.5$ $\mathrm{cm}$ (height)) for mating. To stimulate mating, no prey was added at this time [15]. Twelve hours later, males were removed and separated to other Petri dishes to determine predators capacity. The females were daily supplied with preys on new bean leaves or paper discs and bean pods as oviposition sites until death. Males were also, provided with new preys and bean pods. The number of consumed preys and eggs which females deposited were daily counted under a binocular microscope. Experiments were conducted under three constant temperatures $\left(22,26\right.$ and $30{ }^{\circ} \mathrm{C}$ ), $60 \% \pm 5 \% \mathrm{RH}$ and 16:8 L/D photoperiod.

\subsection{Statistical Analysis}

Significance of the effects of different temperatures and two preys and prey consumption was determined by analysis of variance (ANOVA) (one-way). The mean values were compared using Tukey's test at the $p$ $=0.05$ level of significance. Adult prey consumption and adult longevity were analyzed by two-way ANOVA. Statistical analyses were run in SPSS for Windows version 18.

\section{Results and Discussion}

\subsection{Effect of Temperature on the Duration of Immature Stages of O. similis}

\subsubsection{Incubation Period}

Data in Table 1 and graphically in Fig. 1 showed that the shortest mean incubation period was $2.3 \pm 0.60$ $\mathrm{d}$ at $30{ }^{\circ} \mathrm{C}$. At $26{ }^{\circ} \mathrm{C}$, the mean incubation period increased to $5.1 \pm 0.51 \mathrm{~d}$. Therefore the longest mean incubation period was $10.7 \pm 0.12 \mathrm{~d}$ at $22{ }^{\circ} \mathrm{C}$. It was obvious that the incubation period decreased significantly with each increase of temperature. This result agreed with the findings of Zhang et al. [3], Isenhor and Yeargan [12] and Askari and Stern [16]. Data of statistical analysis shown that temperature has a highly significant effect on the incubation period $(F=$ 4.672 and $p<0.05$ ).

\subsubsection{Duration of Nymphal Stage}

The data in Table 1 and Fig. 1 showed clearly that the longest nymphal developmental period was $23.7 \pm$ $1.1 \mathrm{~d}$ at $22{ }^{\circ} \mathrm{C}$ and the shortest was $13.1 \pm 0.81 \mathrm{~d}$ at $30{ }^{\circ} \mathrm{C}$. At $26^{\circ} \mathrm{C}$, the mean nymphal developmental period lasted $17.5 \pm 0.94 \mathrm{~d}$. In this case it was clear that the duration of nymphal stage decreased significantly with temperature ( $F=2.413$ and $p<0.05$ ). These result agreed with the finding of Zhang et al. [3].

\subsubsection{Total Developmental Period}

Data of the total developmental periods under three constant temperatures are presented in Table 1 and Fig. 1. The shortest mean total developmental period was $15.4 \pm 1.17 \mathrm{~d}$ at $30{ }^{\circ} \mathrm{C}$. At $26{ }^{\circ} \mathrm{C}$, the mean total developmental periods increased to $22.1 \pm 0.63 \mathrm{~d}$, 
Table 1 Effect of three degrees of temperatures $\left(22,26\right.$ and $\left.30{ }^{\circ} \mathrm{C}\right)$ on the development of Orius similis immature stages at $60 \%$ $\pm 10 \%$ RH and 16:8 L/D photoperiod.

\begin{tabular}{llllll} 
Temperatures & No. of replicates & $\begin{array}{l}\text { Incubation period (d) } \\
\text { Mean } \pm \text { SE }\end{array}$ & $\begin{array}{l}\text { Nymphal period } \\
\text { Mean } \pm \text { SE }\end{array}$ & $\begin{array}{l}\text { Total developmental period } \\
\text { Mean } \pm \text { SE }\end{array}$ & $\begin{array}{l}\text { Survival rate (\%) } \\
\text { Mean } \pm \text { SE }\end{array}$ \\
\hline $22{ }^{\circ} \mathrm{C}$ & 10 & $10.7 \pm 0.12^{\mathrm{c}}$ & $23.7 \pm 1.1^{\mathrm{c}}$ & $31.0 \pm 1.02^{\mathrm{c}}$ & $70.59 \pm 2.08^{\mathrm{b}}$ \\
$26^{\circ} \mathrm{C}$ & 10 & $5.1 \pm 0.51^{\mathrm{b}}$ & $17.5 \pm 0.94^{\mathrm{b}}$ & $22.1 \pm 0.63^{\mathrm{b}}$ & $81.14 \pm 1.42^{\mathrm{c}}$ \\
$30^{\circ} \mathrm{C}$ & 10 & $2.3 \pm 0.60^{\mathrm{a}}$ & $13.1 \pm 0.81^{\mathrm{a}}$ & $15.4 \pm 1.17^{\mathrm{a}}$ & $38.78 \pm 0.98^{\mathrm{a}}$ \\
\hline
\end{tabular}

Values (mean $\pm \mathrm{SE}$ ) followed by different letters within a column are significantly different based on Tukey's test with $p<0.05$.

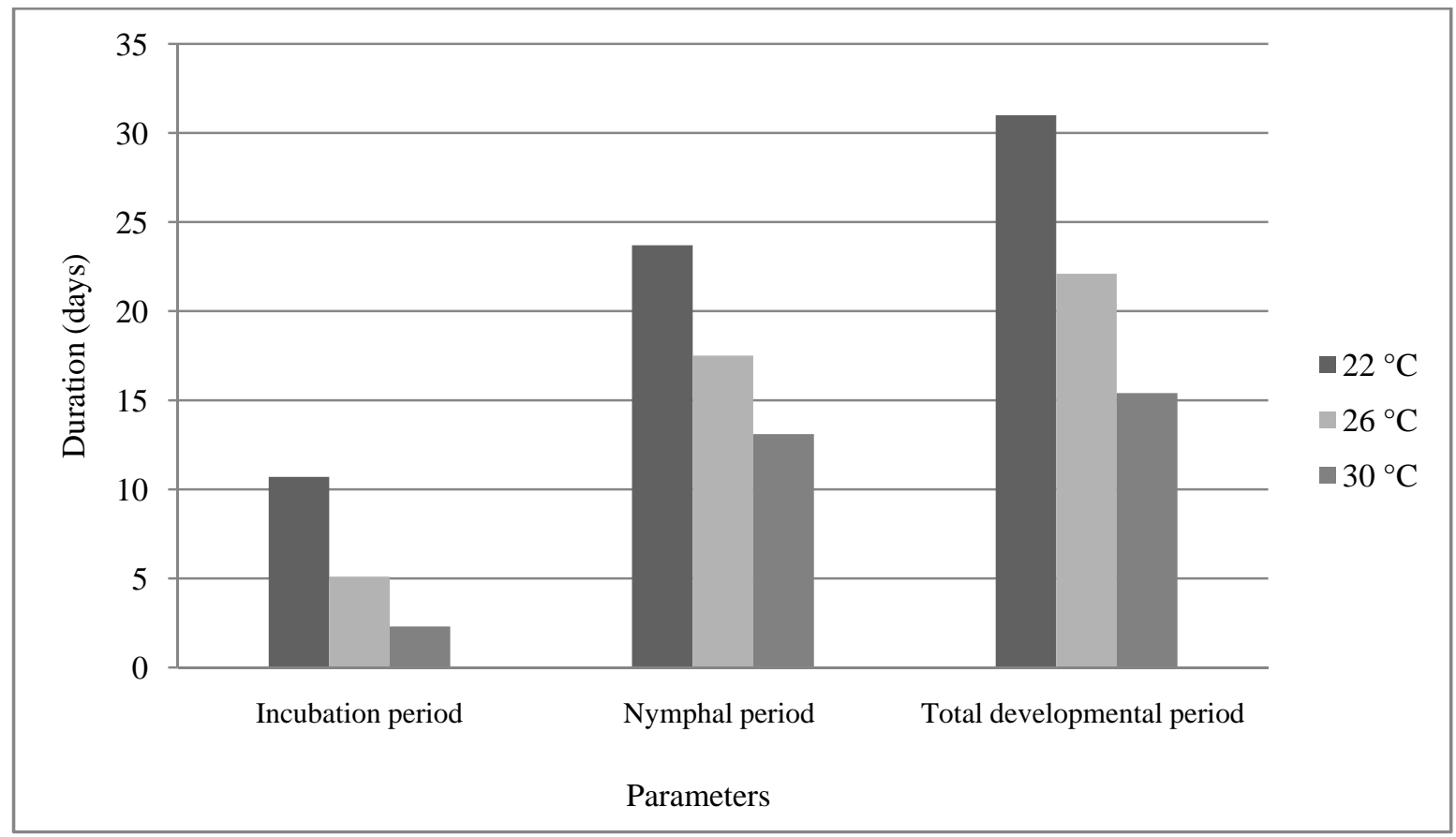

Fig. 1 Effect of different temperatures $\left(22,26\right.$ and $\left.30^{\circ} \mathrm{C}\right)$ on the development of Orius similis immature stages.

whereas, the longest mean total developmental period was $31.0 \pm 1.02 \mathrm{~d}$ at $22{ }^{\circ} \mathrm{C}$. Statistical analysis of data revealed highly significant differences among the total developmental periods under three constant temperatures $(F=6.175$ and $p<0.05)$.

\subsubsection{Survival Rate (\%)}

Data on Table 1 and Fig. 1 showed the effects of three constant temperatures on the percentage of survival rate. The lowest mean survival rate was 38.78\% recorded at $30{ }^{\circ} \mathrm{C}$. While at $22{ }^{\circ} \mathrm{C}$, the mean survival rates increased to $70.59 \%$. On the other hand, the highest mean survival rate was $81.14 \%$ at $26{ }^{\circ} \mathrm{C}$. Statistical analysis of the data (F-test) has shown that there were significant differences between survival rates among data of all tested temperatures $(F=21.542$ and $p<0.05)$.
3.1.5 Effect of Temperature on the Percentage of Hatchability of $O$. similis Egg Stages

Data in Table 2 and Fig. 2 showed that the number of hatched individuals was $51.0 \pm 5.81$ at $26{ }^{\circ} \mathrm{C}$ and decreased to reach $38.1 \pm 4.83$ and $22.9 \pm 11.17$ at $22{ }^{\circ} \mathrm{C}$ and $30 \pm 1{ }^{\circ} \mathrm{C}$, respectively. The effect of temperature was studied, i.e., 22, 26 and $30 \pm 1{ }^{\circ} \mathrm{C}$, $60 \% \pm 10 \% \mathrm{RH}$ and photoperiod of $16: 8 \mathrm{~L} / \mathrm{D}$ on the percentage of hatchability of $O$. similis egg stages. The lowest hatchability was $33.8 \%$ recorded in $30{ }^{\circ} \mathrm{C}$ and increased to reach $58 \%$ at $22{ }^{\circ} \mathrm{C}$, while the highest hatchability was $78 \%$ recorded at $26^{\circ} \mathrm{C}$. It is clear that the temperature $26{ }^{\circ} \mathrm{C}$ was the best temperature for hatchability. The statistical analysis of data revealed highly significant differences among the three temperatures and their effects on hatchability $(F=12.433$ 
Table 2 Effect of three degrees of temperatures $\left(22,26\right.$ and $\left.30{ }^{\circ} \mathrm{C}\right)$ on the percentage of hatchability of $\mathrm{O}$. similis eggs stage at $60 \% \pm 10 \% \mathrm{RH}$ and $16: 8 \mathrm{~L} / \mathrm{D}$ photoperiod.

\begin{tabular}{|c|c|c|c|c|}
\hline $\begin{array}{l}\text { Parameters } \\
\text { Temperatures }\end{array}$ & No. of replicates & Initial No. of eggs & $\begin{array}{l}\text { Hatched individuals } \\
\text { Mean } \pm \text { SE }\end{array}$ & $\begin{array}{l}\text { Hatchability (\%) } \\
\text { Mean } \pm \text { SE }\end{array}$ \\
\hline $22^{\circ} \mathrm{C}$ & 10 & 65 & $38.1 \pm 4.83^{\mathrm{b}}$ & $58 \pm 3.34^{\mathrm{b}}$ \\
\hline $26^{\circ} \mathrm{C}$ & 10 & 65 & $51.0 \pm 5.81^{c}$ & $78 \pm 5.68^{c}$ \\
\hline $30^{\circ} \mathrm{C}$ & 10 & 65 & $22.9 \pm 11.17^{\mathrm{a}}$ & $33.8 \pm 10.47^{\mathrm{a}}$ \\
\hline
\end{tabular}

Values (mean \pm SE) followed by different letters within a column are significantly different based on Tukey’s test with $p<0.05$.

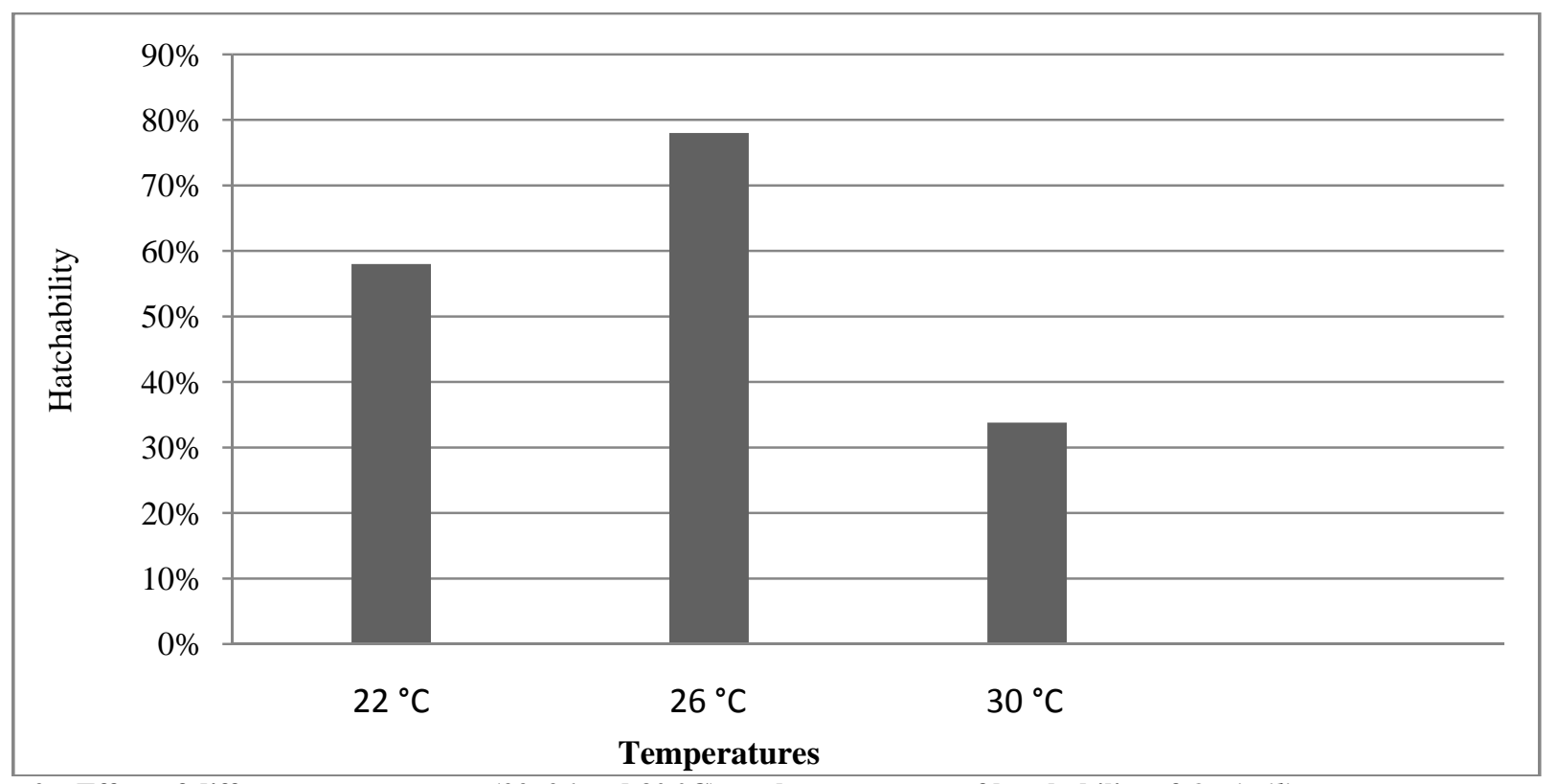

Fig. 2 Effect of different temperatures $\left(22,26\right.$ and $\left.30^{\circ} \mathrm{C}\right)$ on the percentage of hatchability of $O$. similis eggs stage.

and $p<0.001)$ and the number of hatched individuals $(F=6.897$ and $p<0.05)$. These results agreed with Refs. [16-19].

\subsection{Effect of Temperature on Adults}

3.2.1 Effect of Temperature on Pre-oviposition and Oviposition Period

Data recorded in Table 3 and Fig. 3 showed that the shortest pre-oviposition period was $3.0 \pm 0.23 \mathrm{~d}$ at $30{ }^{\circ} \mathrm{C}$ and increased to $7.1 \pm 0.08 \mathrm{~d}$ at $22{ }^{\circ} \mathrm{C}$, when at $26^{\circ} \mathrm{C}$ was $5.2 \pm 1.04 \mathrm{~d}$. It is clear that pre-oviposition period increased by increasing the temperature $(F=$ 4.017 and $p<0.05)$. Data on Table 3 showed that the oviposition period were $20.6 \pm 2.24 \mathrm{~d}$ and $16.1 \pm 1.58$ d at $22{ }^{\circ} \mathrm{C}$ and $26{ }^{\circ} \mathrm{C}$, respectively. When the oviposition period decreased to reached to $11.4 \pm 3.50$ $\mathrm{d}$ at $30{ }^{\circ} \mathrm{C}$. It was obvious that the pre-oviposition period decreased significantly with each increase of temperature $(F=6.251$ and $p<0.05)$.

\subsubsection{Sex Ratio}

The data of sex ratio (females \%) are presented in Table 3 and Fig. 4. The lowest sex ratio was $43.0 \%$ for nymphs reared at $22{ }^{\circ} \mathrm{C}$. While at $26^{\circ} \mathrm{C}$, the mean sex ratio increased to $50.0 \%$. On the other hand, the highest percent was $66.0 \%$ for nymphs reared at $30{ }^{\circ} \mathrm{C}$. Statistical analysis of the data (ANOVA) followed by Tukey's test has shown that there was highly significant effects of the examined temperature on the sex ratio of $O$. similis $(F=4.104$ and $p<0.05)$ [20].

\subsubsection{Female Fecundity}

The data obtained of female fecundity are presented in Table 3 and Fig. 5. The lowest mean female fecundity was $40.0 \pm 8.08$ eggs at $30{ }^{\circ} \mathrm{C}$, while at $22{ }^{\circ} \mathrm{C}$, the mean female fecundity increased to $53.0 \pm$ 10.17 eggs. On the contrary, the greatest mean female fecundity was $62.0 \pm 7.19$ eggs at $26^{\circ} \mathrm{C}$. It was clear 
Table 3 Effect of three degrees of temperatures $\left(22,26\right.$ and $\left.30^{\circ} \mathrm{C}\right)$ on the productivity, longevity and fecundity of adults of O. similis at $60 \% \pm 10 \% \mathrm{RH}$ and $16: 8 \mathrm{~L} / \mathrm{D}$ photoperiod.

\begin{tabular}{|c|c|c|c|c|c|c|c|}
\hline \multirow{3}{*}{$\begin{array}{l}\text { Parameters } \\
\text { tures }\end{array}$} & \multirow{3}{*}{$\begin{array}{l}\text { No. of } \\
\text { replicates }\end{array}$} & \multicolumn{2}{|c|}{ Duration (d) } & \multirow{2}{*}{\multicolumn{2}{|c|}{$\begin{array}{l}\text { Longevity } \\
\text { Mean } \pm \text { SE }\end{array}$}} & \multirow{3}{*}{$\begin{array}{l}\text { Sex ratio } \\
\text { females (\%) }\end{array}$} & \multirow{3}{*}{$\begin{array}{l}\text { Fecundity No. of } \\
\text { eggs/female } \\
\text { Mean } \pm \text { SE }\end{array}$} \\
\hline & & \multirow{2}{*}{$\begin{array}{l}\text { Pre-oviposition } \\
\text { period }\end{array}$} & \multirow{2}{*}{$\begin{array}{l}\text { Oviposition } \\
\text { period }\end{array}$} & & & & \\
\hline & & & & Female & Male & & \\
\hline $22{ }^{\circ} \mathrm{C}$ & 10 & $7.1 \pm 0.08^{\mathrm{b}}$ & $20.6 \pm 2.24^{b}$ & $36.0 \pm 3.17^{c}$ & $19.6 \pm 7.24^{b}$ & $43^{\mathrm{a}}$ & $53.0 \pm 10.17^{b}$ \\
\hline $26^{\circ} \mathrm{C}$ & 10 & $5.2 \pm 1.04^{\mathrm{b}}$ & $16.1 \pm 1.58^{\mathrm{a}}$ & $30.1 \pm 4.99^{\mathrm{b}}$ & $15.9 \pm 5.89^{b}$ & $50^{\mathrm{b}}$ & $62.0 \pm 7.19^{c}$ \\
\hline $30^{\circ} \mathrm{C}$ & 10 & $3.0 \pm 0.23^{\mathrm{a}}$ & $11.4 \pm 3.50^{\mathrm{a}}$ & $26.6 \pm 5.14^{\mathrm{a}}$ & $12.1 \pm 5.07^{\mathrm{a}}$ & $66^{\mathrm{c}}$ & $40.0 \pm 8.08^{\mathrm{a}}$ \\
\hline
\end{tabular}

Values (mean \pm SE) followed by different letters within a column are significantly different based on Tukey’s test with $p<0.05$.

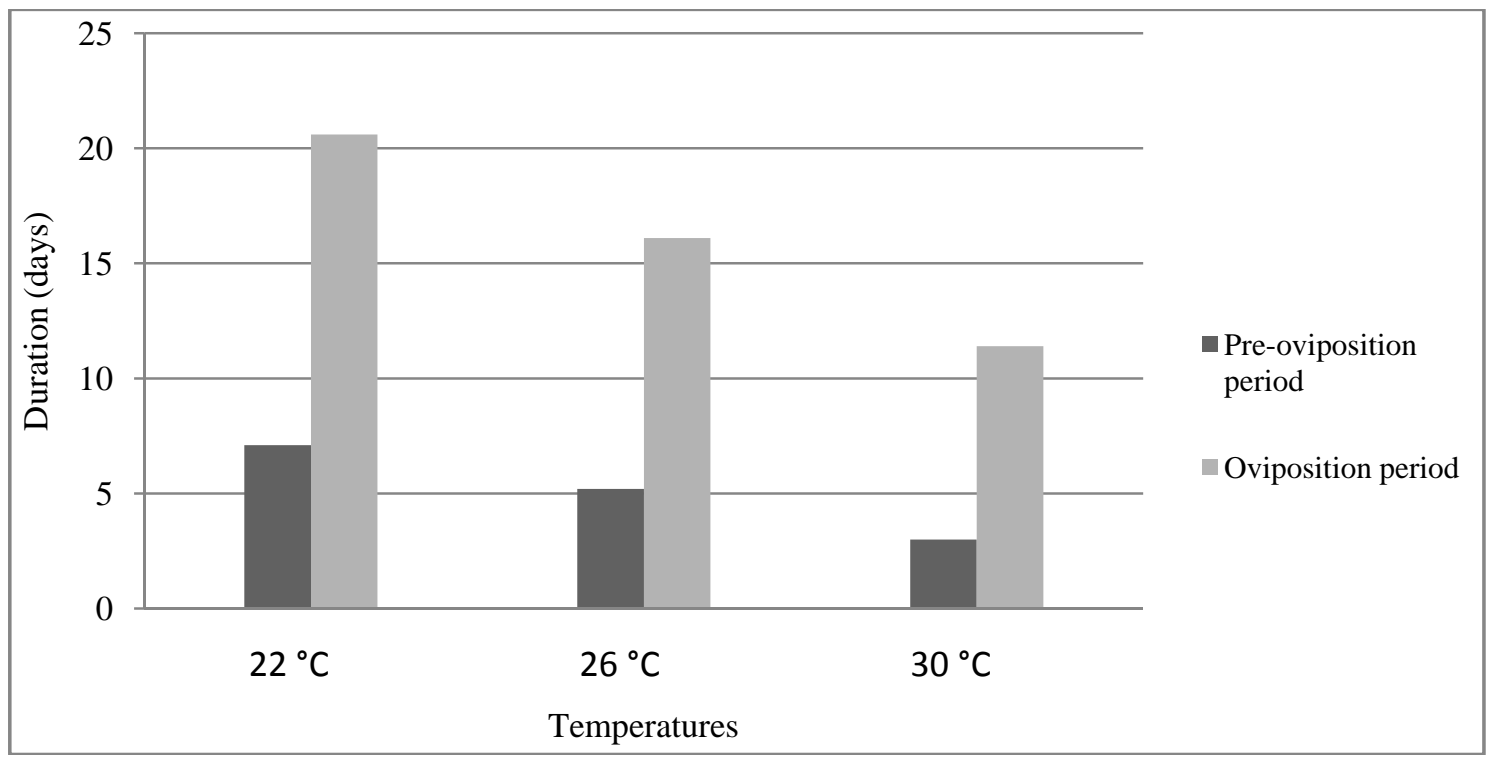

Fig. 3 Effect of different temperatures $\left(22,26\right.$ and $\left.30^{\circ} \mathrm{C}\right)$ on the duration of pre-oviposition and oviposition period of $O$. similis females.

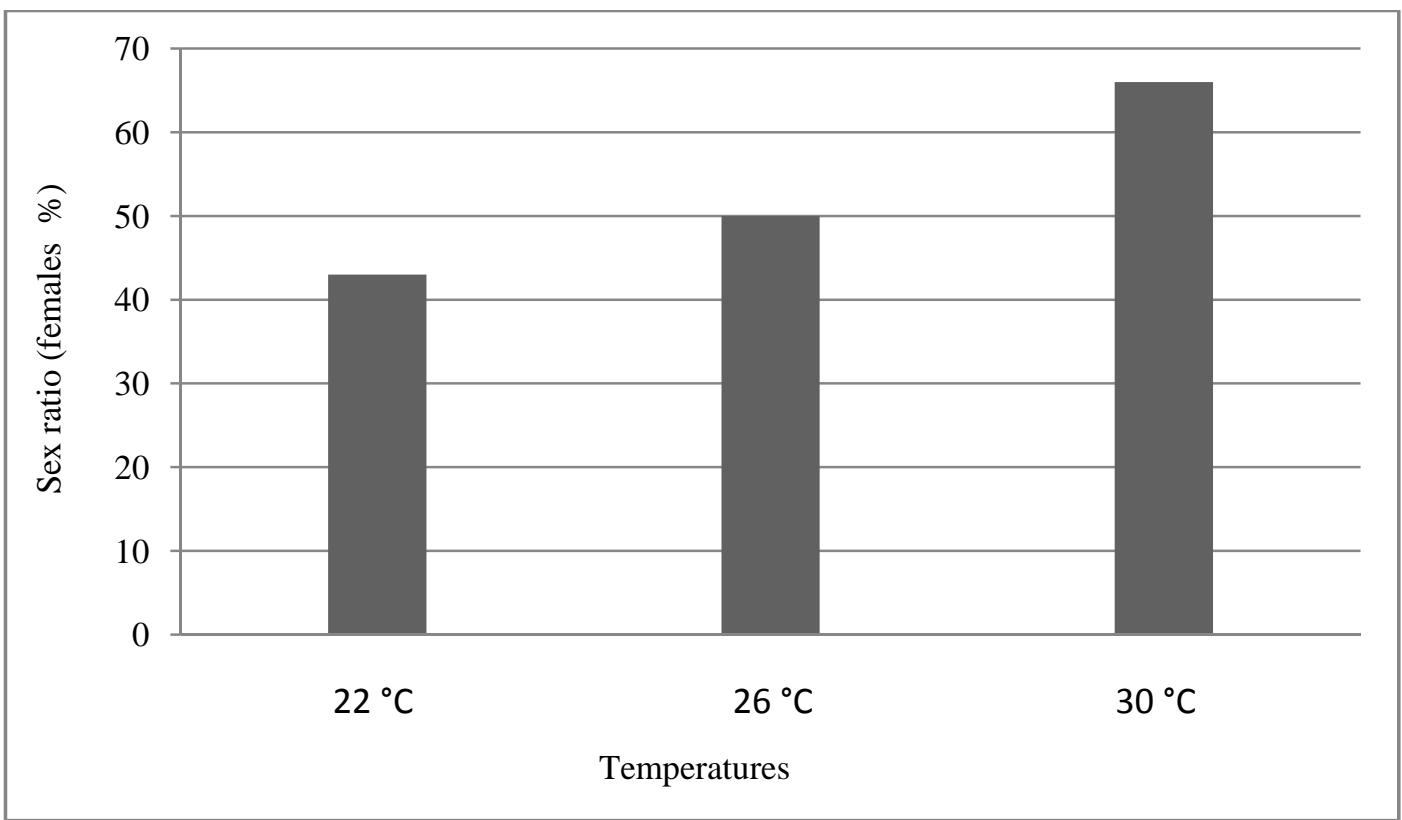

Fig. 4 Effect of different temperatures $\left(22,26\right.$ and $\left.30^{\circ} \mathrm{C}\right)$ on the female percent among the progeny of $O$. similis females. 
that the female fecundity differed significantly among investigated temperatures $(F=13.018$ and $p<0.05)$. Here, female fecundity increased with temperature progressed and peaked at $26{ }^{\circ} \mathrm{C}$ then decreased gradually. This indicated that $26{ }^{\circ} \mathrm{C}$ is the ideal temperature for lab mass rearing. These results in general, agreed with those of Refs. [21-23].

3.2.4 Effect of Temperature on Adult Female Longevity

Data of female longevity are presented in Table 3 and Fig. 6. The shortest average female longevity was
$26.6 \pm 5.14 \mathrm{~d}$ at $30{ }^{\circ} \mathrm{C}$, while at $26{ }^{\circ} \mathrm{C}$, it increased to $30.1 \pm 4.99 \mathrm{~d}$. The longest mean female longevity was $36.0 \pm 3.17 \mathrm{~d}$ at $22{ }^{\circ} \mathrm{C}$. Obviously, the female longevity decreased significantly with temperature increased $(F=3.874$ and $p<0.05)$. These results agreed completely with Alauzet et al. [21], Van de Veire and De Gheele [24] and Sengonca et al. [25].

3.2.5 Effect of Temperature on Adult Male Longevity

The shortest average male longevity was $12.1 \pm 5.07$ d at $30{ }^{\circ} \mathrm{C}$, while at $26^{\circ} \mathrm{C}$, these averages increased to

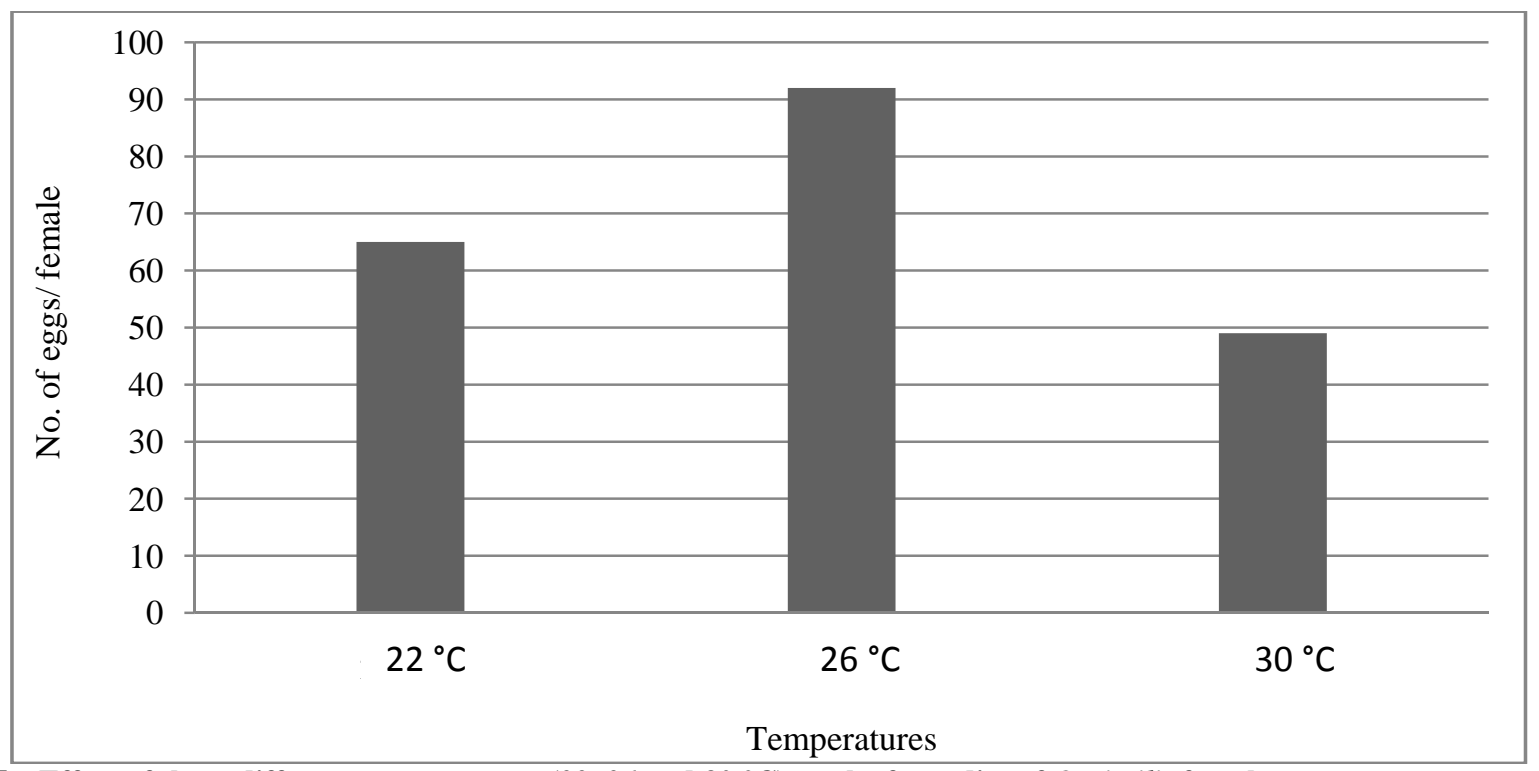

Fig. 5 Effect of three different temperatures $\left(22,26\right.$ and $\left.30^{\circ} \mathrm{C}\right)$ on the fecundity of $O$. similis females.

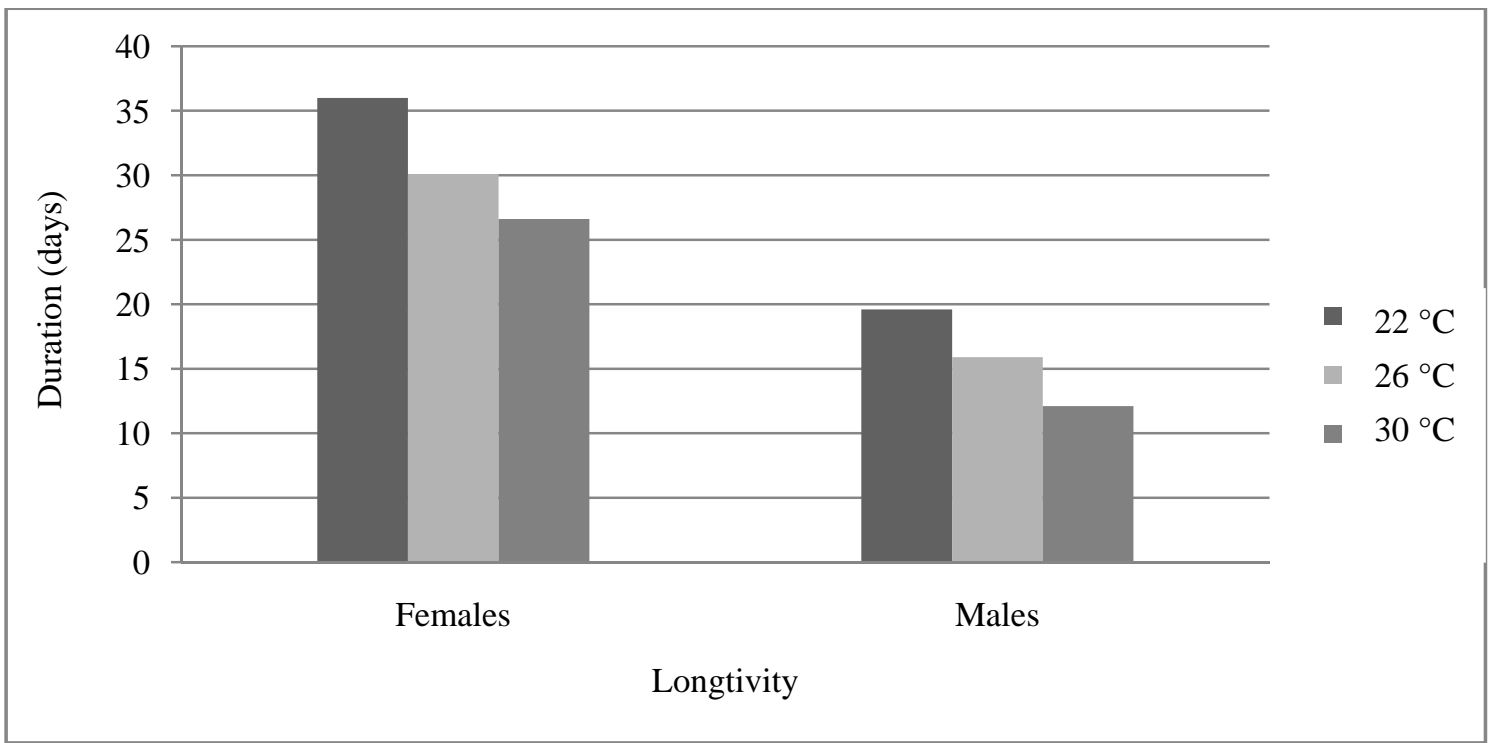

Fig. 6 Effect of different temperatures $\left(22,26\right.$ and $\left.30^{\circ} \mathrm{C}\right)$ on the adult longevity of $O$. similis. 
$15.96 \pm 5.89 \mathrm{~d}$. The longest mean female longevity was $19.6 \pm 7.24 \mathrm{~d}$ at $22{ }^{\circ} \mathrm{C}$. Also, male longevity decreased significantly as temperature increased $(F=17.198$ and $p<0.05)$.

\subsection{Effect of Two Preys on the Development of $O$.} similis

3.3.1 Effect of Two Preys on the Development of Immature Stages

Data on Table 4 and Fig. 7 showed the effect of preys on the percentages of survival rate. The lowest mean survival rate was $65.4 \% \pm 0.48 \%$ for individuals fed on $C$. cephalonica, while the mean survival rates increased to $77.9 \% \pm 1.03 \%$ for individuals fed on $A$. cracivora. On the other hand, the highest mean survival rate was $81.14 \%$ at $26^{\circ} \mathrm{C}$. Statistical analysis of the data (F-test) showed that there were significant differences among the survival rates at all the tested temperatures $(F=11.851$ and $p<0.001)$.

3.3.2 Effect of Two Preys on the Duration of Pre-oviposition and Oviposition Period

Data in Table 5 and graphically in Fig. 8 showed that the shortest mean pre-oviposition and oviposition period were $4.6 \pm 0.08 \mathrm{~d}$ and $7.9 \pm 0.17 \mathrm{~d}$ when females fed on eggs of $C$. cephalonica. Whereas, the longest mean of pr-oviposition and oviposition period

Table 4 Effect of two preys on the development of immature stages of $O$. similis at $26 \pm 1{ }^{\circ} \mathrm{C}, 60 \% \pm 10 \% \mathrm{RH}$ and $16: 8 \mathrm{~L} / \mathrm{D}$ photoperiod.

\begin{tabular}{|c|c|c|c|c|}
\hline Preys & No. of replicates & $\begin{array}{l}\text { Incubation period } \\
\text { Mean } \pm \text { SE }\end{array}$ & $\begin{array}{l}\text { Nymphal period } \\
\text { Mean } \pm \text { SE }\end{array}$ & $\begin{array}{l}\text { Survival rate (\%) } \\
\text { Mean } \pm \text { SE }\end{array}$ \\
\hline C. cephalonica & 10 & $2.8 \pm 0.09^{\mathrm{a}}$ & $18.8 \pm 0.99^{\mathrm{a}}$ & $65.4 \pm 0.48^{\mathrm{a}}$ \\
\hline A. cracivora & 10 & $7.9 \pm 1.28^{\mathrm{b}}$ & $29.9 \pm 1.05^{\mathrm{b}}$ & $77.9 \pm 1.03^{b}$ \\
\hline
\end{tabular}

Values (mean \pm SE) followed by different letters within a column are significantly different based on Tukey's test with $p<0.05$.

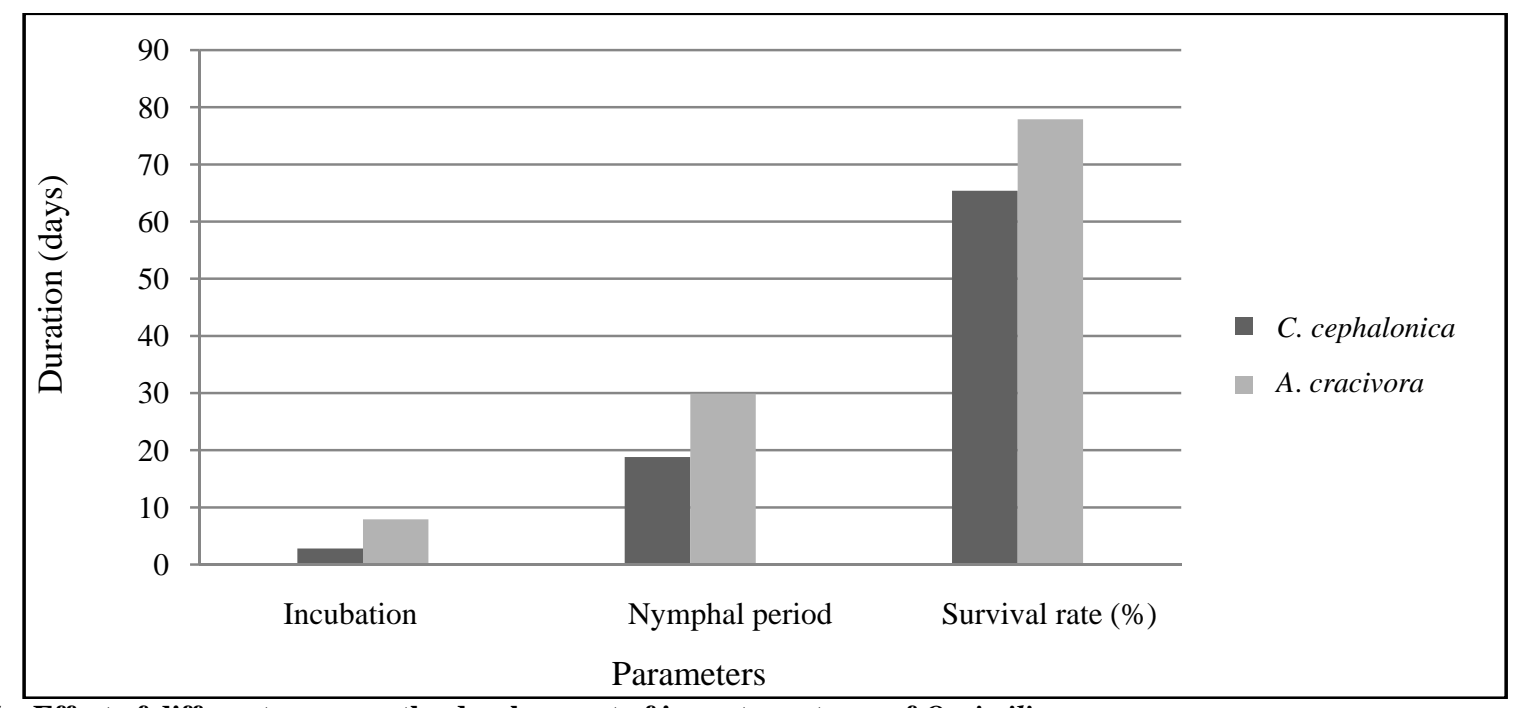

Fig. 7 Effect of different preys on the development of immature stages of $O$. similis.

Table 5 Effect of two preys on the productivity, longevity and fecundity of $O$. similis females at $60 \% \pm 10 \% \mathrm{RH}$ and $16: 8$ L/D photoperiod.

\begin{tabular}{|c|c|c|c|c|c|c|c|}
\hline \multirow{2}{*}{ Prey } & \multirow{2}{*}{$\begin{array}{l}\text { No. of } \\
\text { replicates }\end{array}$} & \multicolumn{2}{|c|}{$\begin{array}{c}\text { Duration }(\mathrm{d}) \\
\text { Mean } \pm \mathrm{SE} \\
\end{array}$} & \multicolumn{2}{|c|}{$\begin{array}{l}\text { Longevity } \\
\text { Mean } \pm \text { SE }\end{array}$} & \multirow{2}{*}{ - Sex ratio (\%) } & \multirow{2}{*}{$\begin{array}{l}\text { Fecundity } \\
\text { No. of eggs/female } \\
\text { Mean } \pm \text { SE }\end{array}$} \\
\hline & & $\begin{array}{l}\text { Pre-oviposition } \\
\text { period }\end{array}$ & $\begin{array}{l}\text { Oviposition } \\
\text { period }\end{array}$ & Female & Male & & \\
\hline C. cephalonica & 10 & $4.6 \pm 0.08^{a}$ & $7.9 \pm 0.17^{\mathrm{a}}$ & $25.7 \pm 2.51^{a}$ & $10.0 \pm 5.01^{a}$ & $38.0^{\mathrm{a}}$ & $44.7 \pm 1.78^{a}$ \\
\hline A. cracivora & 10 & $8.3 \pm 1.15^{b}$ & $15.6 \pm 0.25^{b}$ & $35.1 \pm 2.10^{\mathrm{a}}$ & $14.2 \pm 4.21^{\mathrm{a}}$ & $52.0^{\mathrm{b}}$ & $85.3 \pm 1.18^{\mathrm{b}}$ \\
\hline
\end{tabular}

Values (mean \pm SE) followed by different letters within a column are significantly different based on Tukey's test with $p<0.05$. 


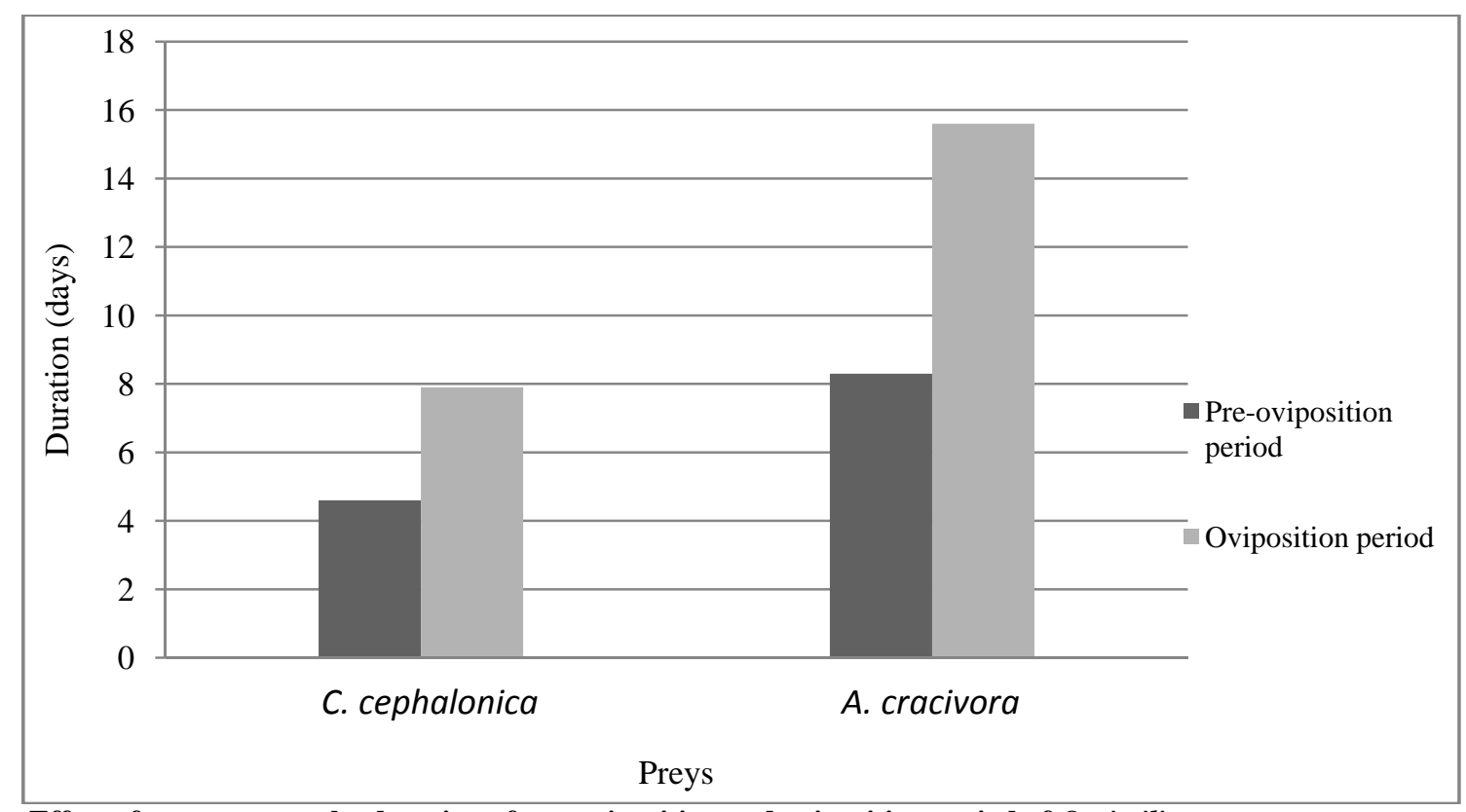

Fig. 8 Effect of two preys on the duration of pre-oviposition and oviposition period of $O$. similis.

were $8.3 \pm 1.15 \mathrm{~d}$ and $15.6 \pm 0.25 \mathrm{~d}$ when females fed on A. cracivora. There were significant differences between pre-oviposition and oviposition period and all tested preys $(F=2.247$ and $p<0.05 ; F=5.752$ and $p$ $<0.05$ ). These results agreed with Calixto et al. [8] and Tommasini et al. [26].

3.3.3 Effect of Two Preys on the Female Longevity

The data of female longevity is summarized in Table 5 and Fig. 9. The shortest mean female longevity was $25.7 \pm 2.51 \mathrm{~d}$ when females fed on eggs of C. cephalonica and increased to $35.1 \pm 2.10 \mathrm{~d}$ when females fed on A. cracivora. This agrees with that recorded by Tommasini and Nicoli [27], Kim et al. [28] and Nishimori et al. [29]. Statistical analysis (F-test) showed that there was significant difference on the female longevity when females fed on eggs of C. cephalonica or A. cracivora ( $F=4.285$ and $p<$ 0.05).

\subsubsection{Effect of Two Preys on the Male Longevity}

The effect of different preys on male longevity was also shown in Table 5 and Fig. 9. The shortest mean male longevity was $10.0 \pm 5.01 \mathrm{~d}$ when males fed on eggs of C. cephalonica and increased to $14.2 \pm 4.21 \mathrm{~d}$ when males fed on A. cracivora. Statistical analysis of the data (F-test) shown that there were low significant effects on the male longevity when fed on two tested preys ( $F=2.017$ and $p<0.05$ ). This agrees with that recorded by Zhang et al. [3] and Tommaini et al. [9].

3.3.5 Effect of Two Preys on the Female Fecundity

The lowest mean female fecundity was $44.7 \pm 1.78$ eggs when the females fed on C. cephalonica and increased to $85.3 \pm 1.18$ eggs when the females fed on A. cracivora. Statistical analysis of the data (F-test) showed that there were highly significant effects on the females fecundity when fed on two tested preys ( $F$ $=14.187$ and $p<0.001$ ) (Table 5 and Fig. 10). These data are agreed with Tommasini and Nicoli [27], Richard and Schmidt [30].

\subsubsection{Effect of Two Preys on the Sex Ratio}

The data obtained of sex ratio are presented in Table 5 and Fig. 11. The lowest sex ratio was 38.0\% when the females fed on C. cephalonica and increased to $52.0 \%$ when the females fed on A. cracivora [10, 31]. Statistical analysis of the data (F-test) has shown that tested preys have significant effects on the sex ratio (females \%) of $O$. similis, so there was significant effect on the sex ratio when adults fed on eggs of $C$. cephalonica and A. cracivora $(F=5.317$ and $p<0.05)$. 


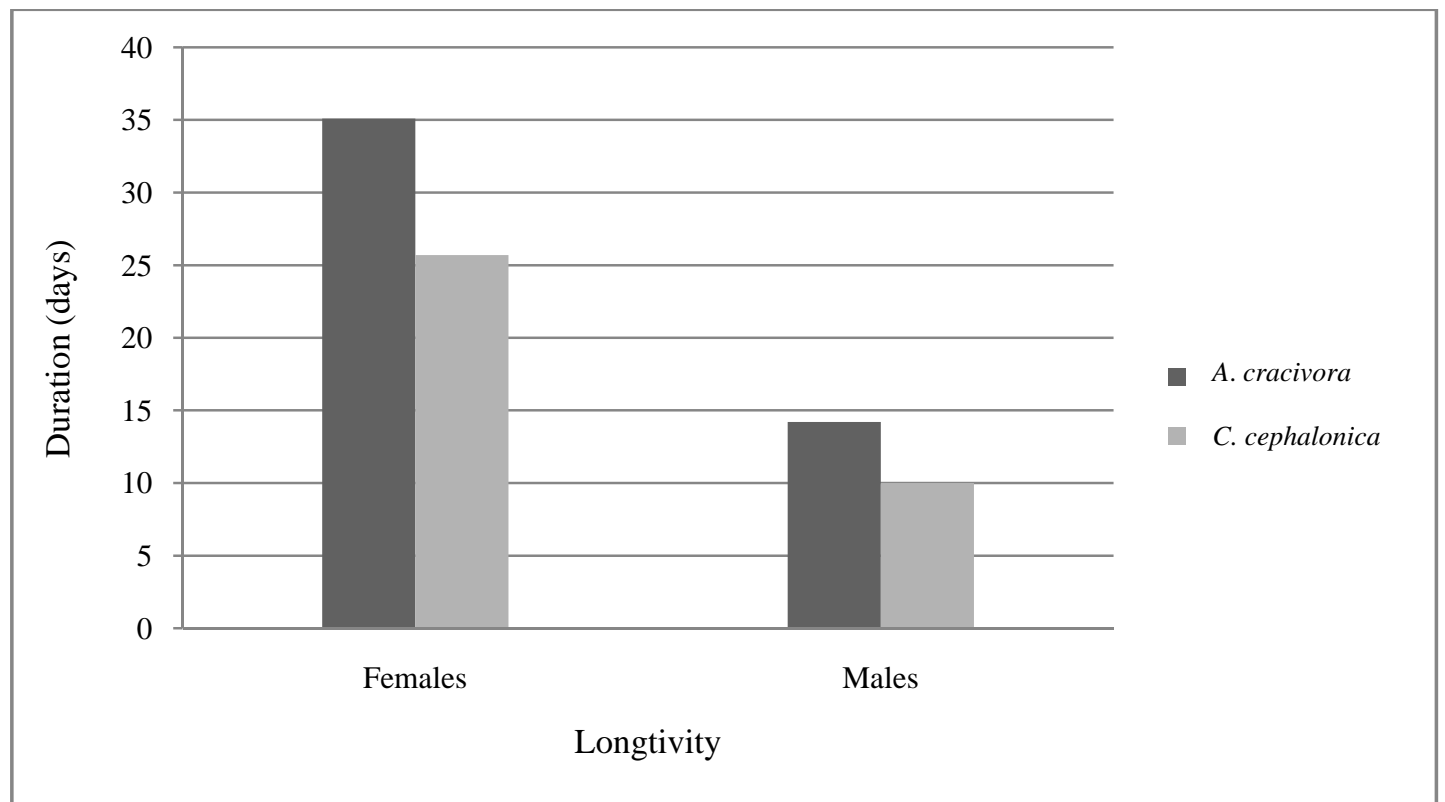

Fig. 9 Effect of two preys on the adult longevity of $O$. similis.

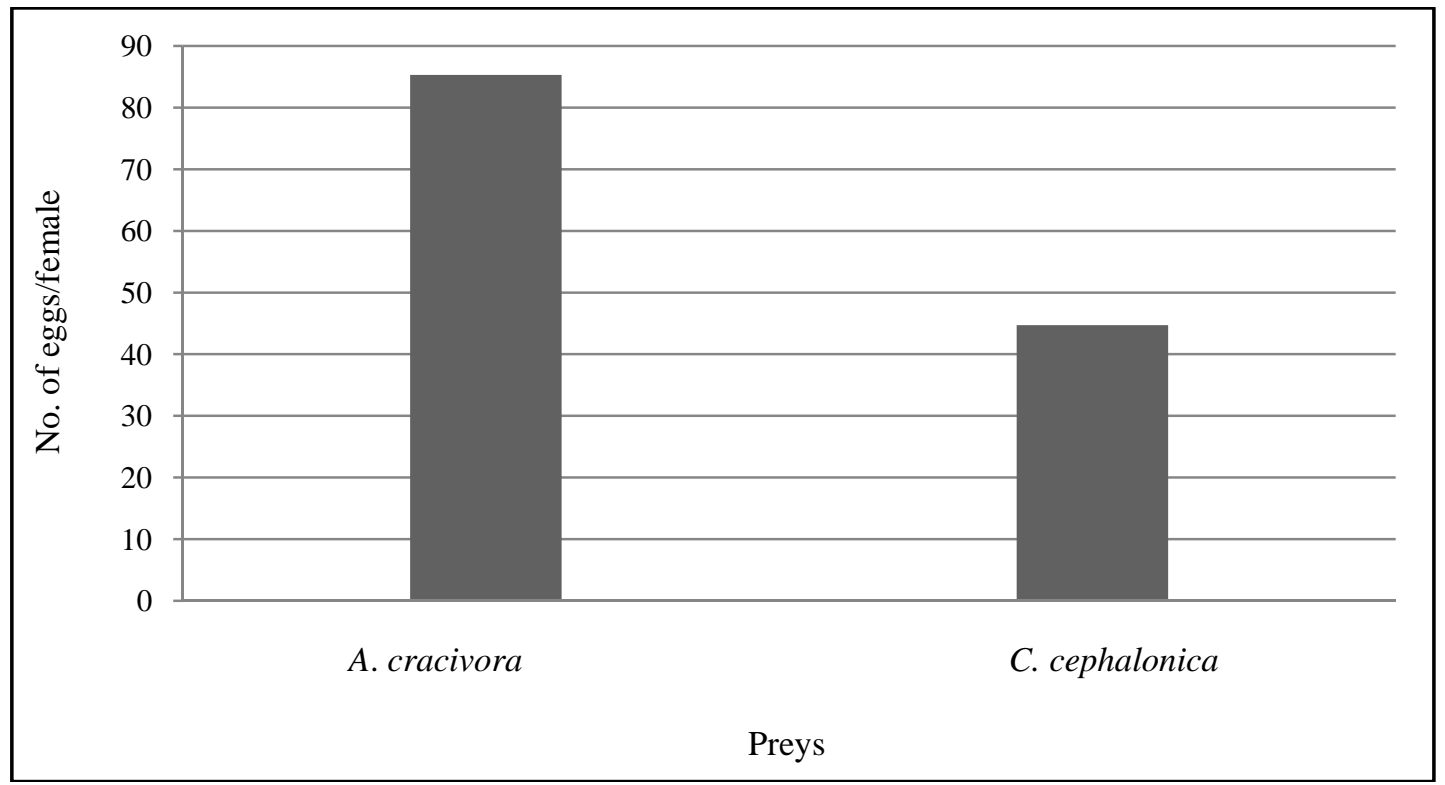

Fig. 10 Effect of two preys on the fecundity of $O$. similis females.

3.4 Effect of Three Temperatures and Two Preys on the Feeding Consumption of $O$. similis

3.4.1 Effect of Temperature and Eggs of $C$. cephalonica on the Feeding Consumption of $O$. similis

\subsubsection{Nymphal Feeding Consumption}

The data obtained of the feeding consumptions of nymphal stage are presented in Table 6 and Fig. 12. The lowest mean feeding consumption of nymphal stages was $43 \pm 1.02$ eggs at $22{ }^{\circ} \mathrm{C}$, while at $26^{\circ} \mathrm{C}$ and $30{ }^{\circ} \mathrm{C}$, the mean feeding consumptions of nymphal stages increased to $67.0 \pm 0.05$ eggs and $51.0 \pm 0.08$ eggs, respectively. So the greatest mean feeding consumption of nymphal stage was at $26{ }^{\circ} \mathrm{C}$. There was highly significant effects of the examined temperatures on the feeding consumption of nymphal stage ( $F=4.080$ and $p$ $<0.05)$. These results agreed with Wang [31] and Sobhy et al. [32] who found that feeding consumption was 
positively correlated with temperature up to $30^{\circ} \mathrm{C}$.

\subsubsection{Male Feeding Consumption}

The lowest mean feeding consumption of males was $20.7 \pm 1.06$ eggs at $22{ }^{\circ} \mathrm{C}$, while at $26^{\circ} \mathrm{C}$ and $30{ }^{\circ} \mathrm{C}$, the mean of the feeding consumption of males stage increased to $39 \pm 3.24$ eggs and $28.5 \pm 2.18$ eggs, respectively. The highest mean of male consumption was occurred on $26^{\circ} \mathrm{C}$, the statistical analysis recorded high significance between the tested temperature and the male feeding consumption $(F=6.227$ and $p<0.05)$.

\subsubsection{Female Feeding Consumption}

The lowest mean of male feeding consumption was $78.9 \pm 4.31$ eggs at $22{ }^{\circ} \mathrm{C}$, while at $26{ }^{\circ} \mathrm{C}$ and $30{ }^{\circ} \mathrm{C}$, mean of the feeding consumption of male stage increased to $143.9 \pm 2.54$ eggs and $102.9 \pm 6.14$ eggs, respectively. The highest mean of male consumption was occurred on $26{ }^{\circ} \mathrm{C}(F=23.114$ and $p<0.001)$.

3.4.2. Effect of Temperature and Nymphs of $A$. craccivora on the Feeding Consumption of $O$. similis

\subsubsection{Nymphal Feeding Consumption}

Data obtained in Table 6 and Fig. 13 showed that the lowest mean consumption of the total nymphal stage was $72.0 \pm 5.18$ nymphs at $22^{\circ} \mathrm{C}$, while at $26^{\circ} \mathrm{C}$ and $30{ }^{\circ} \mathrm{C}$, the mean feeding consumption of male stage increased to $122.5 \pm 3.12$ nymphs and $79.1 \pm 5.88$ nymphs, respectively ( $F=3.451$ and $p<0.05)$.

\subsubsection{Male Feeding Consumption}

The lowest mean consumption of the males was 45.8 \pm 1.85 nymphs, while the highest mean consumption of the males was $98.4 \pm 1.04$ nymphs at $26^{\circ} \mathrm{C}$ and the mean consumption of males consumption at $30^{\circ} \mathrm{C}$ was $58.9 \pm 2.07(F=6.441$ and $p<0.05)$.

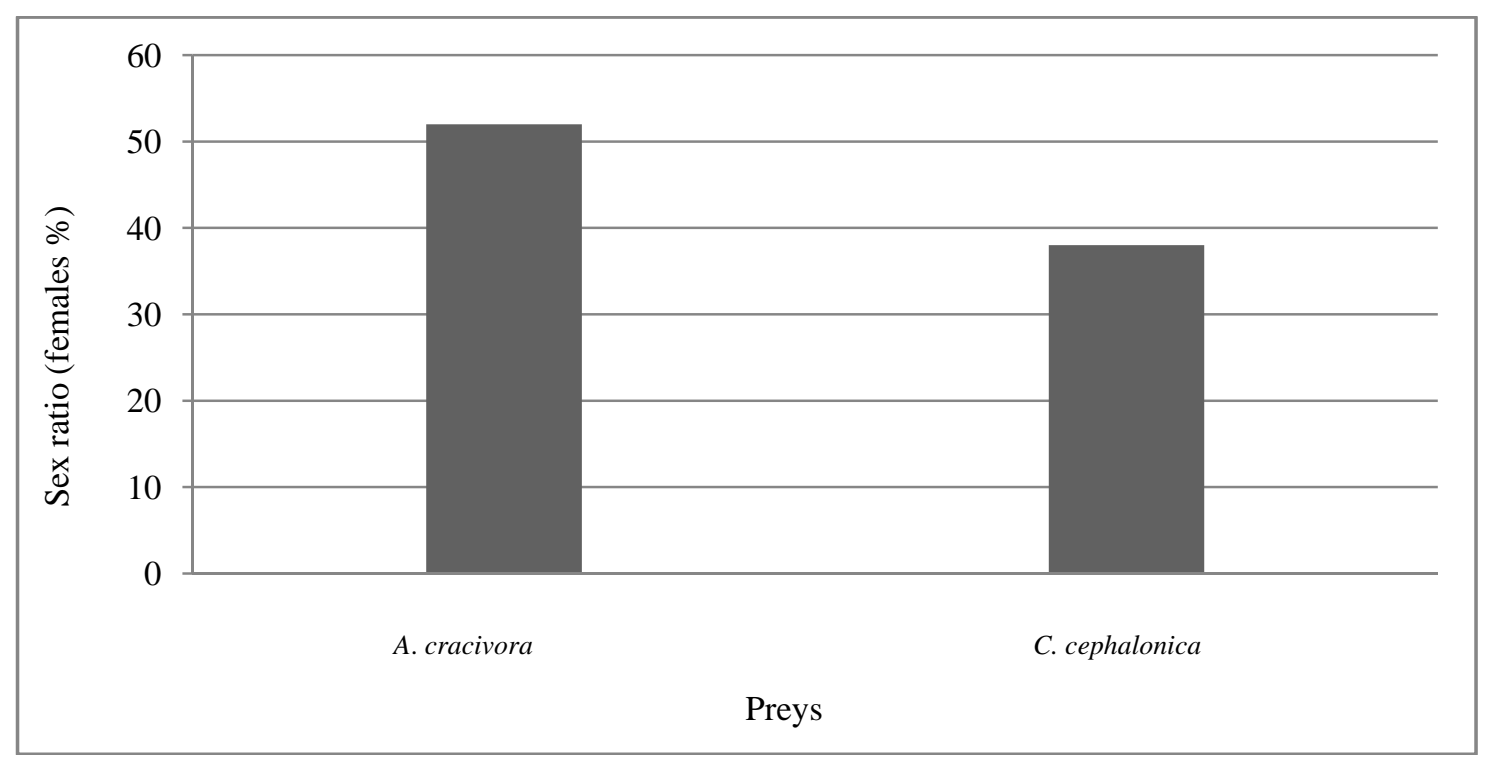

Fig. 11 Effect of two preys on the female percent among the progeny of $O$. similis.

Table 6 Effect of three degrees of temperatures (22, 26 and $30{ }^{\circ} \mathrm{C}$ ) on predation capacity of $O$. similis reared on two different preys.

\begin{tabular}{lllll}
\hline \multirow{2}{*}{ Prey } & \multirow{2}{*}{ Temperature } & \multicolumn{3}{c}{ Consumption efficiency } \\
\cline { 3 - 5 } & & Nymphal feeding consumption & Male feeding consumption & Female feeding consumption \\
\hline \multirow{3}{*}{ C. cephalonica } & $22^{\circ} \mathrm{C}$ & $43.0 \pm 1.02^{\mathrm{a}}$ & $20.7 \pm 1.06^{\mathrm{a}}$ & $78.9 \pm 4.31^{\mathrm{a}}$ \\
& $30^{\circ} \mathrm{C}$ & $67.0 \pm 0.05^{\mathrm{c}}$ & $39.0 \pm 3.24^{\mathrm{b}}$ & $143.9 \pm 2.54^{\mathrm{c}}$ \\
\hline \multirow{3}{*}{ A. cracivora } & $51.0 \pm 0.08^{\mathrm{b}}$ & $28.5 \pm 2.18^{\mathrm{b}}$ & $102.9 \pm 6.14^{\mathrm{b}}$ \\
& $22^{\circ} \mathrm{C}$ & $72.0 \pm 5.18^{\mathrm{a}}$ & $45.8 \pm 1.85^{\mathrm{a}}$ & $151.7 \pm 8.71^{\mathrm{c}}$ \\
& $26^{\circ} \mathrm{C}$ & $122.5 \pm 3.12^{\mathrm{c}}$ & $98.4 \pm 1.04^{\mathrm{b}}$ & $218.9 \pm 17.68^{\mathrm{a}}$ \\
\hline
\end{tabular}

Values (mean \pm SE) followed by different letters within a column are significantly different based on Tukey’s test with $p<0.05$. 


\section{Constant Temperatures}

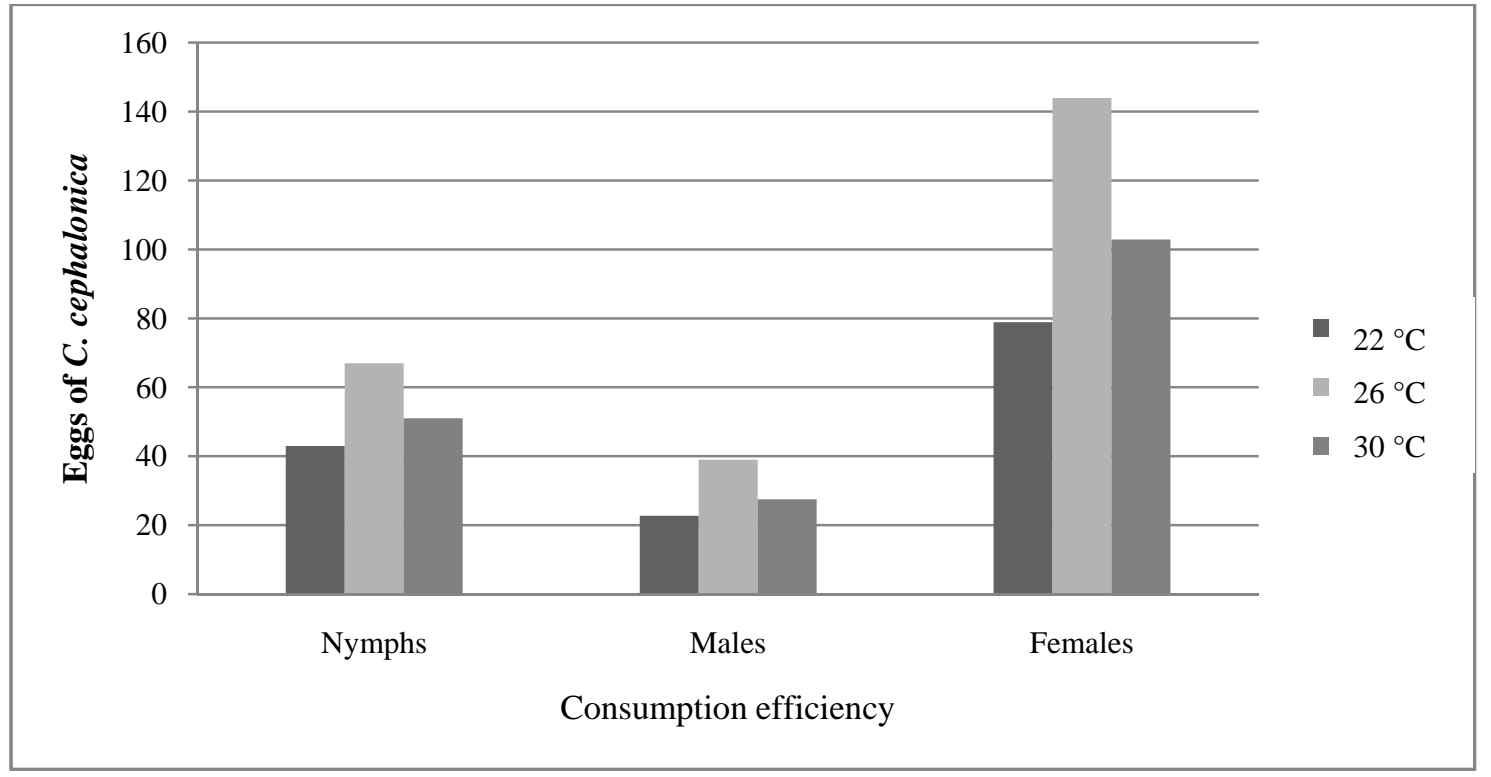

Fig. 12 Effect of different temperatures $\left(22,26\right.$ and $\left.30^{\circ} \mathrm{C}\right)$ on the feeding consumption of $O$. similis on eggs of $C$. cephalonica.

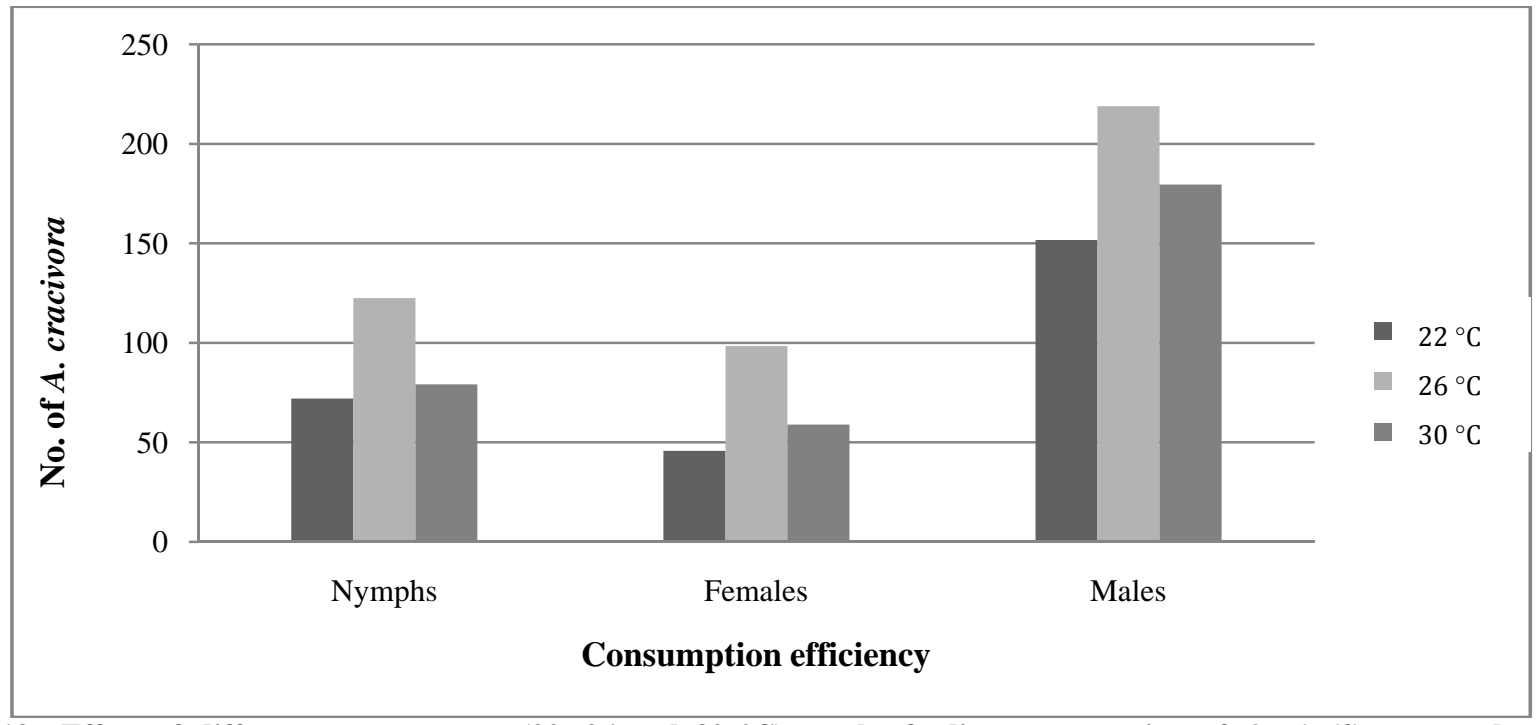

Fig. 13 Effect of different temperatures $\left(22,26\right.$ and $\left.30^{\circ} \mathrm{C}\right)$ on the feeding consumption of $O$. similison nymphs of $A$. cracivora.

\subsubsection{Female Feeding Consumption}

The lowest mean feeding consumption of female was $151.7 \pm 8.71$ nymphs, while the highest mean consumption of the females was $218.9 \pm 17.68$ nymphs at $26{ }^{\circ} \mathrm{C}$ and the mean of the female consumption at $30^{\circ} \mathrm{C}$ was $179.5 \pm 10.31$ nymphs $(F=$ 12.701 and $p<0.001)$.

The highest mean consumptions of nymph, male and female were all founded at $26{ }^{\circ} \mathrm{C}$. In accordance with these results, Mccaffrey and Horsburgh [33, 34] found that feeding consumption was positively correlated with temperature; the feeding consumption was higher when the nymph, male and female fed on A. cravivora compared with eggs of C. cephalonica [8].

\section{Conclusions}

In this paper, the obtained results showed that the development of immature stages (eggs and nymphs) of $O$. similis was decreased with each increase of 
temperature; the longest mean developmental period of nymphal stages was $31.0 \pm 1.02 \mathrm{~d}$ at $22{ }^{\circ} \mathrm{C}$. At $30{ }^{\circ} \mathrm{C}$, the mean developmental periods of nymohal stages was increased to $15.4 \pm 1.17 \mathrm{~d}$. The shortest mean incubation period was $2.3 \pm 0.60 \mathrm{~d}$ at $30^{\circ} \mathrm{C}$. At $26^{\circ} \mathrm{C}$, the mean incubation period increased to $5.1 \pm$ $0.51 \mathrm{~d}$. The survival rate (\%) was $81.14 \%$ at $26^{\circ} \mathrm{C}$ and decreased to $38.78 \%$ at $30{ }^{\circ} \mathrm{C}$. About the effect of temperatures on hatchability of eggs, the highest hatchability was $78 \%$ recorded at $26{ }^{\circ} \mathrm{C}$ and the number of hatched individuals was increased in each increased of temperatures. As well as, the pre-oviposition and oviposition period and longevity were decreased significantly with each increase of temperature. The highest female fecundity was recorded at $26{ }^{\circ} \mathrm{C}(62.0 \pm 7.19$ eggs $)$. Regarding to the effect of two preys on the development of immature stages, the data showed that, the longest mean of pre-oviposition and oviposition period were $8.3 \pm 1.15$ and $15.6 \pm 0.25$ when females fed on A. cracivora and the longest female longevity was $35.1 \pm 2.10 \mathrm{~d}$ when females fed on A. cracivora.

\section{Acknowledgments}

Many thanks to Prof. Dr. Yueguan Fu for his supervision and supporting, also many thanks to all group of Department of Integrated Pest Management for supporting and facilitating the work. This study was supported by the National Key R \& D Program of China (No. 2017YFD0202100) and the earmarked fund for China Agriculture Research System (No. CARS-34-BC2). Sincere appreciation to Environmental and Plant Protection Institute (EPPI), Chinese Academy of Tropical Agricultural Science (CATAS), Talented Young Scientist Program (TYSP), Department of International Cooperation, MOST (http://www.most.gov.cn), China Science and Technology Exchange Center (http://www.cstec.org.cn) for encouragement and financial support.

\section{References}

[1] Cloyd, R. A., and Sadof, C. S. 1998. “Aphids: Biology and Management.” Floriculture Indian 12 (2): 3-7.

[2] Devi, N., Gupta, P. R., Sharma, K. C., Sharma, P. L., and Negi, B. R. 2018. "Fertility Table Parameters of Predatory Bug Orius bifilarus Ghauri (Hemiptera: Anthocoridae) Preying upon Thrips palmi and Eggs of Corcyra cepholinica.” Int. J. Curr. Microbiol. App. Sci. 7 (3): 2574-86.

[3] Zhang, S. C., Zheng, F. X., Lei, C. L., and Zhou, X. M. 2012. "Survival and Developmental Characteristics of the Predatory Bug Orius similis (Hemiptera: Anthocoridae) Fed on Tetranychus cinnabarinus (Acari: Tetranychidae) at Three Constant Temperatures.” Eur. J. Entomol. 109: 503-8.

[4] Zhou, X. M., Zhu, F., Li, H., and Lei, C. L. 2006. "Effect of Temperature on Development of Orius similis Zheng (Hemiptera: Anthocoridae) and on Its Predation Activity against Aphis gossypii Glover (Homoptera: Aphididae).” Pan-Pacific Entomol. 82 (1): 97-102.

[5] Zong, L. B., Zong, C. Z., Lei, Z. L., Peng, C. W., and Wu, M. R. 1987. "Predation Efficacy of Orius similis on the Eggs of Pink Bollworm, Pectinophora gossypiella." Chinese Journal of Biological Control 3: 87. (in Chinese)

[6] Butler, C. D., and O’Neil, R. J. 2007. "Life History Characteristics of Orius insidiosus (Say) Fed Aphis glycines Matsumura.” Biol. Control. 40: 333-8.

[7] Zhou, X. M., and Lei, C. L. 2002. "Utilization Efficiency and Functional Response of Orius similis Zheng (Hemiptera: Anthocoridae) to Different Preys.” Acta Ecologica Sinica 22 (12): 2085-90.

[8] Calixto, A. M., Bueno, V. H. P., Montes, F. C., Silva, A. C., and Van-Lenteren, J. C. 2013. "Effect of Different Diets on Reproduction, Longevity and Predation Capacity of Orius insidiosus (Say) (Hemiptera: Anthocoridae).” Biocontrol Science and Technology 23 (11): 1245-55.

[9] Tommaini, M. G., Van-Leentren, J. C., and Burgio, G. 2004. "Biological Traits and Predation Capacity of Four Orius Species on Two Prey Species.” Bulletin of Insectology 57 (2): 79-93.

[10] Bonte, M., and De-Clerco, P. 2011. "Influence of Predator Density Diet and Living Substrate on Developmental Fitness of Orius laevigatus.” J. Appl. Entomol. 135: 343-50.

[11] Mangoud, A. A. H. 2003. Personal Communication with Research Worker Working on Mass Rearing of Predators during Working in the Project 604.

[12] Isenhor, D. J., and Yeargan, K. V. 1981. "Effect of Temperature on the Development of Orius insidiosus with Notes on Laboratory Rearing." Ann Entomol. Soc. Am. 74 (1): 114-6. 
[13] Isenhour, D. J., and Yeargan, K. V. 1981. "Predation by Orius insidiosus on the Soybean Thrips, Sericothrips varialilis: Effect of Prey Stage and Density.” Environ. Entomol. 10: 496-500.

[14] El-Husseini, M., Schumann, K., and Serman, H. 1993. "Rearing Immature Feeding Stage of Orius majusculus Reut. on the Acarid Mite Tyrophagus putrescentiae Schr. as a New Alternative Prey.” J. Appl. Entomol. 116: 113-7.

[15] Ortigosa, A., and Rowe, L. 2002. "The Effect of Hunger on Mating Behaviour and Sexual Selection for Male Body Size in Gerris buenoi.” Anim. Behav. 64: 369-75.

[16] Askari, A., and Stern, V. M. 1972. "Effect of Temperature and Photoperiod on Orius tristicolor Feeding on Tetranychus pacificus.” J. Econ. Entomol. 65 (1): 132-5.

[17] Tommasini, M. G., and Nicoli, G. 1994. "Pre-imaginal Activity of Four Orius Species Reared on Two Preys." Bulletin OILB SROP 17 (5): 237-41.

[18] Vacante, V., Couzza, G. E., De Cleroi, P., Van Do Veire, M., and Tirry, L. 1997. "Development and Survival of Orius albidipennis and Orius laevigatus (Het.: Anthocoridae) on Various Diets.” Entomophaga 42 (4): 493-8.

[19] Hussini, M., Agamy, E., and Sayed, S. M. H. 2000. "Comparative Biological Studies on Immatures of Orius albidipennis and $O$. laevigatus (Heteroptera: Anthocoridae) Reared on Two Different Preys.” Egy. J. Biol. Pest Contr. 10 (2): 81-8.

[20] Sobhy, I. S., Sarhan, A. A., Shokhry, A. A., El-Kady, G. A., and Mandour, N. S. 2006. "Effects of Different Temperature Levels on the Biological Attributes of Orius albidipennis (Reuter) (Hemiptera: Anthocoridae).” J. Agric. Res. Suez. Canal. Univ. 6: 213-6.

[21] Alauzet, C., Darganon, D., and Malausa, J. C. 1994. "Bionomics of a Polyphagous Predator: Orius laevigatus (Heteroptera: Anthocoridae).” Entomophaga 39 (1): 33-40.

[22] Cocuzza, G. E., De Clercqi, P., Lizzio, S., Van De Veire, M., Tirry, L., and Degheelie, D. 1997. "Life Tables and Predation Activity of Orius laevigatus and $O$. albidipennis at Three Constant Temperatures.” Entomol. Exp. Appl. 189-98.

[23] Nagi, K., and Yano, E. 1999. "Effects of Temperature on Development and Reproduction of Orius sauteri (Poppius) (Heteroptera: Anthocoridae) a Predator of Thrips palmi (Karny) (Thysanoptera: Thripidae).” Appl. Entomol. and Zool. 34 (2) : 223-9.

[24] Van De Veire, M., and De Gheele, D. 1995.
“Comparative Laboratory Experiment with Orius insidiosus and Orius albidipennis (Het.: Anthocoridae), Two Candidates for Biological Control in Glasshouses.” Entomophaga 40 (3-4): 341-4.

[25] Sengonca, C., Ahmadi, K., and Blaesser, P. 2008. "Biological Characteristics of Orius similis Zheng (Heteroptera: Anthocoridae) by Feeding on Different Aphid Species as Prey.” Journal of Plant Diseases and Protection 115 (1): 32-8.

[26] Tommasini, M. G., Benuzzi, M., and Van Lenteren, J. C. 1996. "Influence of Temperature on the Development Time and Adult Activity of Orius laevigatus.” Bulletin OILB SROP 19 (1): 179-82.

[27] Tommasini, M. G., and Nicoli, G. 1993. "Adult Activity of Four Orius Species Reared on Two Preys.” Bulletin IOBC WPRS 16 (2): 181-4.

[28] Kim, J. H., Han, M. W., Lee, G. H., Kim, Y. H., Lee, J. O., and In, C. J. 1997. "Development and Oviposition of Orius strigicollis Poppius (Hemiptera: Anthocoridae) Reared on Three Different Insect Preys.” Korean J. Appl. Entomol. 36: 166-71. (in Korean)

[29] Nishimori, T., Miura, K., and Seko, T. 2016. "Rearing Orius strigicollis (Hemiptera: Anthocoridae) on an Alternative Diet of Brine Shrimp, Artemia salina (Anostraca: Artemiidae)." Applied Entomology and Zoology 51 (2): 321-5.

[30] Richard, P. C., and Schmidt, J. M. 1996. "The Effects of Selected Dietary Supplements on Survival and Reproduction of Orius insidiosus (Say)." Can. Entomol. 128: $171-6$

[31] Wang, C. L. 1995. "Predatory Capacity of Campylomma chinensis Schuh (Hemiptera: Miridae) and Orius sauteri (Poppius) (Hemiptera: Anthocoridae) on Thrips palmi.” In Thrips Biology and Management, Boston: Springer, 259-62.

[32] Sobhy, I. S., Sarhan, A. A., Shoukhry, A. A., El-Kady, G. A., Mandour, N. S., and Reitz, S. R. 2010. "Development, Consumption Rates and Reproductive Biology of Orius albidipennis Reared on Various Prey.” BioControl 55 (6): 753-65.

[33] Mccaffrey, J. P., and Horsburgh, H. R. 1986. "Biology of Orius insidiosus (Heteroptera: Anthocoridae): A Predator in Virginia Apple Orchards.” Environ. Entomol. 15 (4): 984-8.

[34] Mccaffrey, J. P., and Horsburgh, H. R. 1986. "Functional Response of Orius insidiosus (Hemiptera: Anthocoridae) to the European Red Mite, Panonychus ulmi (Acari: Tetranychidae), at Different Constant Temperatures.” Environ. Entomol. 15 (3): 532-5. 